\title{
SANKSI ADAT BATALNYA MELAKSANAKAN PERKAWINAN PADA MASYARAKAT DAYAK DESA (Studi Kasus di Desa Mengkirai Kecamatan Kayan Hilir Kabupaten Sintang)
}

\author{
Gadion, SH,MH \\ Fakultas Hukum Univesitas Kapuas Sintang \\ unkagadion@gmail.com
}

\begin{abstract}
Marriage is a gift from God Almighty as every human desires to find a life partner and build a household until separated by death. In carrying out the marriage, there is a relationship between men and women to come together in family. Hence, in aim to come together between two families, a meeting are needed between the men and women. This meeting are intended to deals with the implementation of the marriage party, annulment of marriage from man or woman which enable to cause a dispute between the two parties. Thus, the recovery must be done by a customary system.
\end{abstract}

In result, the annulment of marriage which performed one-sidedly by both men and women in Dayak Desa community is one of disobedience custom. This is as a responsibility tha must be fulfilled for one party because it has been said as means as "lie" (Ngemula). Customary payments formed as "Tempayan", 1 (rinti) of pig, a chicken, $4 \mathrm{kl}$ rice (6 kulak), iron (nails), sarong cloth (kain Tapih) for opening words of each party Rp. 50,000, and the embarrassment cover money of Rp 1,000.000. These all customary range must be met by the party who annulled the marriage. The factors are caused to annul a marriage namely, the fear of building a household because there is no mental readiness and for not having a permanent job. Thus, the fear arises at the implementation of the marriage.

Based on the conclusions mentioned above, the researcher suggest that range of customs of annulment of a lie marriages (Ngemula) in Mengkirai Desa, Kayan Hilir Subdistrict, Sintang Regency, It must be maintained based on the habits of the Dayak Desa community. Customary administrators in Mengkirai Village, Kayan Hilir Subdistrict, Sintang Regency, it is need to be more improved in socializing disobedience custom in the community. The improvement is needed to reduce the marriage annulment.

Keywords: Sanctions, Customs, The Annulment Marriage

\footnotetext{
Abstract

Perkawinan merupakan anugrah Tuhan Yang Maha Esa, salah satu keinginan
} 

setiap umat manusia adalah mencari pasangan hidup untuk membina rumah tangga sampai maut memisahkan, dalam melaksanakan perkawinan yang dilakukan tentunya terjadi hubungan antara kedua belah pihak baik pihak laki-laki maupun pihak perempuan untuk menyatukan diantara keluarga masingmasing, berkaitan dengan penyatuan kedua keluarga dalam bentuk perkawinan, haruslah dilakukan pertemuan diantara kedua belah pihak baik pihak laki-laki maupun pihak perempuan, terutama mengenai pelaknasaan pesta perkawinan,pembatalan perkawinan yang dilakukan oleh salah satu pihak baik lakilaki maupun perempuan dapat menimbulkan perselisihan antara kedua belah pihak, sehingga harus lah dilakukan pemulihan dengan cara adat.

Metode pendekatan yang digunakan dalam penelitian ini adalah Metode Yuridis Sosiologis yaitu pendekatan masalah melalui penelitian hukum dengan fakta yang ada pada instansi yang bersangkutan ataupun masyarakat sehubungan dengan permasalahan yang ditemui dalam penelitian. Sifat penelitian ini adalah Deskriptif analisis, yaitu suatu penelitan yang menggambarkan secara menyeluruh dari systematis obyek dari pokok permasalahan.

Hasil Penelitian bahawa Pembatalan perkawinan yang dilakukan secara sepihak baik laki-laki maupun perempuan, dalam masyarakat dayak Desa merupakan salah satu adat ingkar, yang mana adat ingkar tersebut haruslah dipenuhi sebagai pertanggungjawaban bagi salah satu pihak karena telah dikatakan berbohong (ngemula). pembayaran adat yang berupa Tempayan, babi 1 rinti, ayam 1 ekor, beras 4 kl (6 kulak), besi (paku), Kain sarung (kain Tapih) uang pembuka kata masing-masing pihak Rp. 50.000, dan uang penutup malu Rp 1.000.00, kisaran adat tersebut haruslah di penuhi oleh pihak yang membatalkan perkawinan. Salah satu faktor membatalkan perkawinan adalah rasa ketakutan untuk membina rumah tangga karena belum ada kesiapan mental salah satunya adalah belum mempunyai pekerjaan yang tetap sehingga rasa ketakutan untuk membina rumah tangga timbul pada saat akan pelaksanaan perkawinan

Berdasarkan uraian-uraian yang penelitisampaikan diatas maka disimpulkan sebagai berikut : Bahwa Pembatalan perkawinan yang dilakukan secara sepihak baik laki-laki maupun perempuan, dalam masyarakat dayak Desa merupakan salah satu adat ingkar, yang mana adat ingkar tersebut haruslah dipenuhi sebagai pertanggungjawaban bagi salah satu pihak karena telah dikatakan berbohong (ngemula). faktor-faktor yang mempengaruhi sehingga batal melaksanakan perkawinan yaitu kesiapan yang belum sempurna, serta kehadiran orang ketiga sehingga mempengaruhi pembatalan perkawinan. 
Berdasarkan kesimpulan

yang penelitisampaikan diatas dapat penelitisarankan sebagai berikut : kisaran adat pembatalan perkawinan ingkar (ngemula)di Desa Mengkirai Kecamatan Kayan Hilir Kabupaten Sintang agar dipertahankan sesuai dengan kebiasaan masyarakat dayak Desa. Pengurus adat di Desa Mengkirai Kecamatan Kayan Hilir Kabupaten Sintang dalam mensosialisasikan adat ingkar pada masyarakat agar lebih ditingkatkan kembali sehingga dalam masyarakat dapat mengurangi terjadinya pembatalan perkawinan yang dilakukan.

Kata Kunci : Sanksi Adat, Batal Perkawinan

\section{PENDAHULUAN}

Dayak merupakan sebutan bagi penduduk asli pulau Kalimantan. Pulau kalimantan terbagi berdasarkan wilayah Administratif yang mengatur wilayahnya masing-masing terdiri dari: Kalimantan Timur ibu kotanya Samarinda, Kalimantan Selatan dengan ibu kotanya Banjarmasin, Kalimantan Tengah ibu kotanya Palangka Raya, dan Kalimantan Barat ibu kotanya Pontianak.

Kelompok Suku Dayak, terbagi lagi dalam sub-sub suku yang kurang lebih jumlahnya 405 sub (menurut J. U. Lontaan, 1975). Masing-masing sub suku Dayak di pulau Kalimantan mempunyai adat istiadat dan budaya yang mirip, merujuk kepada sosiologi kemasyarakatannya dan perbedaan adat istiadat, budaya, maupun bahasa yang khas. Masa lalu masyarakat yang kini disebut suku Dayak, mendiami daerah pesisir pantai dan sungai-sungai di tiap-tiap pemukiman mereka.

Etnis Dayak Kalimantan menurut seorang antropologi J.U. Lontaan, 1975 dalam Bukunya Hukum Adat dan Adat Istiadat Kalimantan Barat, terdiri dari 6 suku besar dan 405 sub suku kecil, yang menyebar di seluruh Kalimantan. Kuatnya arus urbanisasi yang membawa pengaruh dari luar,seperti melayu menyebabkan mereka menyingkir semakin jauh ke pedalaman dan perbukitan diseluruh daerah Kalimantan. ${ }^{1}$

Mereka menyebut dirinya dengan kelompok yang berasal dari suatu daerah berdasarkan nama sungai, nama pahlawan, nama alam dan sebagainya. Misalnya suku Iban asal katanya dari ivan (dalam bahasa kayan, ivan = pengembara) demikian juga menurut sumber yang lainnya bahwa mereka menyebut dirinya dengan nama suku Batang Lupar, karena berasal dari sungai Batang Lupar, daerah perbatasan Kalimantan Barat dengan Serawak, Malaysia. Suku Mualang, diambil dari nama seorang tokoh yang disegani (Manok Sabung/algojo) di Tampun Juah dan nama tersebut diabadikan menjadi sebuah nama anak sungai Ketungau di daerah

1 https://id-id.facebook.com/notes/ stevanus-agung/sejarah-asal-usul-dayak-di-kaliman$\tan / 205141046181327 /$ Hari Selasa 5 Maret 2019 Jam $12.00 \mathrm{wib}$ 
Kabupaten Sintang (karena suatu peristiwa) dan kemudian dijadikan nama suku Dayak Mualang. Dayak Bukit (Kanayatn/Ahe) berasal dari Bukit/gunung Bawang. Demikian juga asal usul Dayak Kayan, Kantuk, Tamambaloh, Kenyah, Benuag, Ngaju dan lain-lain, yang mempunyai latar belakang sejarah sendiri-sendiri. ${ }^{2}$

Namun ada juga suku Dayakyang tidak mengetahui lagi asal usul nama sukunya. Nama "Dayak" atau "Daya"adalah nama eksonim (nama yang bukan diberikan oleh mayarakat itu sendiri) dan bukan nama endonim (nama yang diberikan oleh masyarakat itu sendiri). Kata Dayak berasal dari kata Daya" yang artinya hulu, untuk menyebutkan masyarakat yang tinggal di pedalaman atau perhuluan Kalimantan umumnya dan Kalimantan Barat khususnya, (walaupun kini banyak masyarakat Dayak yang telah bermukim di kota kabupaten dan propinsi) yang mempunyai kemiripan adat istiadat dan budaya dan masih memegang teguh tradisinya. ${ }^{3}$

Berdasarkan wilayah penyebaran di Kalimantan Barat Bangsa Dayak di Kalimantan Barat terbagi berdasarkan sub-sub ethnik yang tersebar diseluruh kabupaten di Kalimantan Barat. Berdasarkan Ethno Linguistik dan cirri cultural gerak tari Dayak di Kalimantan Barat menjadi 4 kelompok besar, 1 kelompok kecil yakni:
1. Kendayan / Kanayatn Grop : Dayak Bukit (ahe), Banyuke, Lara, Darit, Belangin, Bakati” dan lain-lain. Wilayah penyebarannya di Kabupaten Pontianak, Kabupaten Landak, Kabupaten Bengkayang, dan sekitarnya.mempunyai gerak tari, enerjik, stakato, keras.

2. Ribunic / Jangkang Grop/ Bidoih / Bidayuh : Dayak Ribun, Pandu, Pompakng, Lintang, Pangkodatn, Jangkang, Kembayan, Simpakng, dll. Wilayah penyebarannya di Kabupaten Sanggau Kapuas, mempunyai ciri gerak tangan membuka, tidak kasar dan halus.

3. Iban/Ibanic : Dayak Iban dan sub-sub kecil lainnya, Mualang, Ketungau, Kantuk, Sebaruk, Banyur, Tabun, Bugau, Undup, Saribas, Desa, Seberuang, dan sebagainya. Wilayah penyebarannya di Kabupaten Sambas (perbatasan), Kabupaten Sanggau / malenggang dan sekitarnya (perbatasan) Kabupaten Sekadau (Belitang Hilir, Tengah, Hulu) Kabupaten Sintang, Kabupaten Kapuas Hulu, Serawak, Sabah dan Brunai Darusalam. mempunyai ciri gerak pinggul yang dominan, tidak keras dan tidak terlalu halus.

4. Banuaka" Grop : Taman, Tamambaloh dan sub nya, Kalis, dan sebagainya. Wilayah penyebarannya di Kabupaten Kapuas Hulu.ciri gerak mirif kelompok ibanic, tetapi sedikit lebih halus. 
5. Kayaanik, punan, bukat dan lain-lain. ${ }^{4}$

Selain terbagi menurut ethno linguistik yang terdata menurut jumlah besar groupnya, masih banyak lagi yang belum teridentifikasikan gerak tarinya, karena menyebar dan berpencar dan terbagi menjadi suku yang kecil-kecil. Misalnya Dayak Mali / ayek-ayek, terdapat dialur jalan tayan kearah kab. ketapang. kemudian Dayak Kabupaten Ketapang,Daerah simpakng seperti Dayak Samanakng dan Dayak Kualan, daerah Persaguan, Kendawangan, daerah Kayong, Sandai, daerah Krio, Aur kuning. Daerah Manjau dsb.

Kemudian Dayak daerah Kabupaten Sambas, yaitu Dameo / Damea, Sungkung daerah Sambas dan Kabupaten Bengkayang dan sebagainya. Kemudian daerah Kabupaten Sekadau kearah Nanga Mahap dan Nanga Taman, Jawan, Jawai, Benawas, Kematu dan lain-lain. Kemudian Kabupaten Melawi, yaitu: dayak Keninjal(mayoritas tanah pinoh;antara lain desa ribang rabing, ribang semalan, madya raya, rompam, ulakmuid, maris dan lain-lain) dayak Kebahan (antara lain desa:poring,nusa kenyikap, Kayu Bunga, dan lain-lain yang memiliki tari alu dan tari belonok kelenang yang hampir punah), dayak Linoh (antara lain desa:Nanga taum,sebagian ulak muid, mahikam dan lain-lain), dayak pangen (Jongkong, sebagian desa balaiagas dan lain-lain), dayak kubing (antara lain desa 4 http://hamiddarmadi.blogspot. com/2017/02/ayak-asal-usul-dan-penyebarannya-di. htm diakses Hari Selasa 5 Maret 2019 Jam 12.00 wib sungai bakah/sungai mangat, nyanggai, nanga raya dan lain-lain), dayak limai (antara lain desa Tanjung Beringin, tain, menukung, ela dan lain-lain), dayak undau, dayak punan, dayak ranokh/anokh (antara lain sebagian di desa batu buil, sungai raya dan lain-lain), dayak sebruang (antara lain didesa tanjung rimba, piawas dan lain-lain), dayak Ot Danum ( masuk kelompok kal-teng), Leboyan. ${ }^{5}$

Pemberian sanksi adat terhadap pihak yang membatalkan perkawinan bertujuan untuk memberikan rasa jera terhadap keluarga dan pihak yang membatalkan perkawinan, oleh sebab itu sanksi adat tersebut haruslah dipenuhi supaya ada ketenangan diantara keluarga yang merasa dirugikan serta warga masyarakat maupun alam disekitarnya.

Sedangkan perkawinan berdasarkan Undang-Undang Republik Indonesia Nomor 1 Tahun 1974 Tentang Perkawinan Bab I Pasal 1 Perkawinan ialah "ikatan lahir bathin antara seorang pria dengan seorang wanita sebagai suami isteri dengan tujuan membentuk keluarga (rumah tangga) yang bahagia dan kekal berdasarkan Ketuhanan Yang Maha Esa".

Menurut Soetoyo Prawirohamidjojo, Pengertian Perkawinan adalah persekutuan hidup yang terjadi antara seorang pria dan wanita, yang disahkan secara formal dengan undang-undang (yuridis) dan kebanyakan

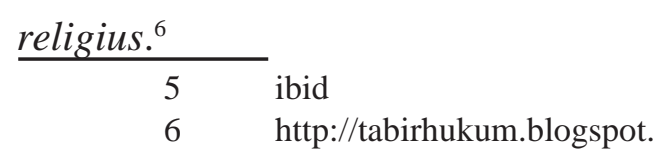
com/2016/11/definisi-perkawinan-menurut-para-ahli. 
Sedangkan Pengertian Perkawinan

Menurut Subekti adalah pertalian sah yang terjadi antara seorang laki-laki dan seorang perempuan untuk waktu yang lama. Dengan demikian Perkawinan merupakan kata yang merujuk pada hal-hal yang terkait dengan sebuah ikatanatau hubungan pernikahan. Pengertian istilah perkawinan lebih luas dari istilah pernikahan. Jika pernikahan merujuk pada sebuah ikatan yang dilakukan atau dibuat oleh pihak suami dan istri untuk hidup bersama, dan atau merujuk pada sebuah proses dari ikatan tersebut, perkawinan merujuk pada hal-hal yang muncul terkait dengan proses pelaksanaan dan akibat dari pernikahan. $^{7}$

Hukum adat merupakan hukum asli Indonesia. Adat sendiri berasal dari bahasa Arab yang berarti kebiasaan. Kebiasaan tersebut ditiru dan akhirnya berlaku untuk seluruh anggota masyarakat. Hukum adat tidak tertulis akan tetapi dipatuhi oleh anggota masyarakat adat. Hukum adat merupakan bentuk dari adat yang memiliki akibat hukum. Hukum adat berbeda dengan hukum tertulis ditinjau dari bentuk sanksi yang diberikan kepada orang yang melakukan pelanggaran.

Bentuk sanksi hukum adat menitikberatkan

html Diakses hari Sabtu 18 Januari 2019 jam 11.00 wib

$7 \quad$ Jamhari Makruf dan Asep Saepudin Jahar, Hukum Keluarga, Pidana Dan Bisnis Kajian Perundang-Undangan Indonesia, Fikih Dan Hukum Internasional (Jakarta: Kencana Prenadamadia Group, 2013), hlm. 24 pada bagian moral serta material, hukum adat tidak mengenal penjara sebagai tempat para terpidana menjalani hukuman yang telah ditetapkan oleh hakim. ${ }^{8}$

Kata adat berasal dari bahasa Arab yang kemudian diadopsi ke dalam bahasa Indonesia yang baku. Kata adat berasal dari kata "ad" yang mempunyai derivasi kata al中adat yang berarti sesuatu yang diulangulang atau dapat dikatakan sebagai kebiasaan. Adat diartikan sebagai "aturan (perbuatan dsb) yang lazim diturut atau dilakukan sejak dahulu kala". ${ }^{9}$

Sedangkan pengertian Kebiasaan merupakan perbuatan yang diulang-ulang dalam bentuk yang sama. Perbuatan itu diulang-ulang membuktikan bahwa orang menyukainya. Jadi kebiasaan (Folkways) merupakan tata cara bertindak yang digemari oleh masyarakat sehingga dilakukan berulangulang oleh banyak orang. Kebiasaan memiliki kekuatan yang lebih besar dari pada tata cara, misalnya memberikan salam waktu bertemu, berterimakasih, menyuci tangan sebelum dan sesudah makan, membungkukkan badan sebagai tanda penghormatan kepada orang yang lebih tua. ${ }^{10}$

Sedangkan menurut Kusumadi

8 Bushar Muhammad, 2006, AsasAsas Hukum Adat, Jakarta: PT. Pradnya Paramita. Hlm. 19.

9 Wikipediabahasa Indonesia, ensiklopedia bebas, https://id.wikipedia.org/wiki/Adat, diakses pada tanggal 10 Oktober 2018, pkl 16.50.

$10 \mathrm{https}: / /$ mellapuspita.wordpress. com/2017/04/14/perbedaan-peradaban-budaya-tradisi-adat-istiadat-dan-kebiasaan/ diakses 30 Nopember 2018 Jam 09:30 WIB 
Pudjojosewojo, mengatakan : "Bahwa adat adalah tingkah laku oleh dan dalam suatu masyarakat (sudah, sedang, akan) diadatkan, adat itu ada yang tebal dan ada yang tipis senantiasa menebal dan menipis". ${ }^{11}$

Menurut Van Vollenhoven hukum adat adalah :"Aturan prilaku yang berlaku bagi orang-orang pribumi dan orang-orang timur asing, yang disuatu pihak mempunyai sanksi (sehingga disebut hukum) dan dilain pihak tidak dikodifikasi (sehuingga dikatakan adat)". ${ }^{12}$

Sedangkan pengertian hukum adat menurut Soekamto dalam bukunya Menuju Hukum Adat Indonesia : "Komplek adat-adat inilah yang kebanyakan tidak dikitabkan, tidak dikodifikasikan dan bersifat paksaan mempunyai sanksi (dari itu hukum), jadi mempunyai akibat hukum, komplek ini disebut hukum adat". ${ }^{13}$

Hukum adat adalah hukum nonstatutair yang sebagian besar adalah hukum kebiasaan dan sebagian kecil adalah hukum Islam. Ia berurat berakar pada kebudayaan tradisional. Sebagian hukum yang hidup, dia menjelmakan persatuan hukum yang nyata dari masyarakat / rakyat. Ia senantiasa tumbuh dan berkembang seperti hidup itu sendiri. ${ }^{14}$

11 Kusumadi, 2004, Pedoman Pelajaran Tata Hukum, Aksara Baru Jakarta. Hal 45

12 I Gede A.B. Wiranata,2005 Hukum Adat Indonesia, Perkembangannya dari Masa Kemasa, PT.Citra Aditiya Bakti, Bandung, Hal:11

13 Soekanto, Meninjau Hukum Adat Indonesia Suatu Pengatar Untuk Mempelajari Hukum Adat, CV Rajawali Jakarta, hal :2

14 I Gede A.B. Wiranata, 2005.
Timbulnya reaksi dari masyarakat adat, atas pelanggaran hukum atau perbuatan yang menyebabkan terjadinya peristiwaadat sehingga mengakibatkan ketidak seimbangan antar kelompok masyarakat dan memperngaruhi kehidupan manusia dan alam sekitarnya merupakan perbuatan yang menyelenggarakan adat sebagai hukum yang selama ini dijunjung tinggi oleh masyarakat adat setempat. Dimana di dalam buku babbab tentang Hukum Adat karya Supomo yang dikutip kembali oleh Bushar Muhammad mengatakan :

Sanksi adat merupakan salah satu aturan adat yang dijalankan bagi setiap pelanggarnya oleh sebab itu sanksi adat diberikan kepada kelompok maupun orang perseorangan yang dikenakan adat. Menurut Dewa Made Suartha menjelaskan bahwa sanksi berasal dari kata sanctum yaitu bahasa latin yang berarti penegasan yang juga disebut dengan bevestiging/bekrachtiging . Penegasan tersebut bisa berarti hal yang positif yaitu hadiah dan juga dapat bersifat negative seperti hukuman. Oleh karena itu sanksi dikatakan sebagai perangsang dalam melakukan sesuatu atau tidak melakukan sesuatu. ${ }^{15}$

Dara Indrawati menjelaskan bahwa terdapat dua jenis pemberlakuan sanksi yakni sanksi yang diberlakukan untuk pelaku sebagai orang yang melanggar dan sanksi yang berlaku

Hukum Adat Indonesia, Perkembangannya dari Masa Kemasa, PT.Citra Aditiya Bakti, Bandung, Hal:17

15 I Made Suartha. 2015. Hukum dan Sanksi Adat. Malang: Setara Press, Hlm. 20 
secara kolektif karena berhubungan dengan kehidupan orang banyak. Contoh kasus penerapan sanksi secara perorangan adalah kasus pembunuhan atau pencurian. Adapun pemberlakuan sanksi secara kolektif dalamhal ini juga berhubungan dengan kedudukan keluarga atas orang yang melakukan pelanggaran sehingga pihak keluarga juga menanggung akibat dari perbuatan anggota keluarganya. ${ }^{16}$

Tujuan pemberian sanksi adat harus mengikuti filosofi penyelesaian sengketa secara adat. Sanksi yang diterapkan haruslah mendukung tujuan penyelesaian sengketa/ kasus scara adat. Filosofi penyelesaian sngekata/kasus secara adat berbeda dengan penyelesaian sengketa/kasus di Pengadilan Formal. Pengadilan bertugas memutuskan perkara untuk menentukan salah tidaknya sesorang, menang atau kalahnya seseorang. Sebaliknya, penyelesaian sengketa/kasus scara adat bukan semata-mata untuk itu, tetapi lebih untuk memulihkan ketentraman dan keharmonisan masyarakat. Setelah diselesaikan secara adat maka para pihak yang bersenketa akan berbaikan kembali seperti semula, pelaku pelanggran adat akan kembali menjadi bagian dari masayarakat dan bisa hidup harmonis lagi dengan masyarakat. ${ }^{17}$ Perkawinan merupakan hubungan antara seorang laki-laki dan perempuan untuk 16 http://www.sarjanaku.com/2013/01/ pengertian-perkawinan-makalah-masalah.html diakses hari Selasa Tanggal 27 Nopember 2017 jam 11.30 wib 17 https://ajiksh.wordpress. com/2016/05/19/macam-macam-jenis-huku- menyatukan diri dalam bentuk keluarga menurut Kamus Besar Bahasa Indonesia (KBBI) Online memberikan penjelasan kata Kawin adalah membentuk keluarga dengan lawan jenis; bersuami atau beristri; menikah. ${ }^{18}$ Perkawinan merupakan institusi yang sangat penting dalam masyarakat. Perkawinan adalah melegalkan hubungan hukum antaraseorang laki-laki dan seorang wanita. ${ }^{19}$ Menurut Bachtiar Definisi Perkawinan adalah pintu bagi bertemunya dua hati dalam naungan pergaulan hidup yang berlangsung dalam jangka waktu yang lama, yang di dalamnya terdapat berbagai hak dan kewajiban yang harus dilaksanakan oleh masing-masing pihak untuk mendapatkan kehidupan yang layak, bahagia, harmonis, serta mendapat keturunan. Perkawinan itu merupakan ikatan yang kuat yang didasari oleh perasaan cinta yang sangat mendalam dari masing-masing pihak untuk hidup bergaul guna memelihara kelangsungan manusia di bumi. ${ }^{20}$

Berdasarkan berbagai definisi tentang perkawinan di atas, dapat disimpulkan bahwa perkawinan merupakan ikatan lahir batin antara laki-laki dan perempuan sebagai suami isteri yang memiliki kekuatan hukum dan diakui secara sosial dengan tujuan man-adat-di-indonesia/ diakses Hari Selasa 5 Maret 2019 Jam 12.00 wib

18 http://Pengertian Bahasa Indonesia .blogspot.co.id/2012/12/diakses hari Selasa Tanggal 27 Nopember 2017 jam 11.30 wib

19 Salim H,S., 2002, Pengantar Hukum Perdat Tertulis(BW), (Jakarta: Sinar Grafika,), hlm 61. 20 http://www.sarjanaku.com/2013/01/ pengertian-perkawinan-makalah-masalah.html diakses hari Selasa Tanggal 27 Nopember 2017 jam 11.30 wib 
membentuk keluarga sebagai kesatuan yang menjanjikan pelestarian kebudayaan dan pemenuhan kebutuhan-kebutuhan hidup bagi setiap pasangan dalam perkawinan. UndangUndang Republik Indonesia Nomor 1 Tahun 1974 Tentang Perkawinan Bab I Pasal 1 menjelaskan pengertian dari Perkawinan ialah "ikatan lahir bathin antara seorang pria dengan seorang wanita sebagai suami isteri dengan tujuan membentuk keluarga (rumah tangga) yang bahagia dan kekal berdasarkan Ketuhanan Yang Maha Esa”.

Berdasarkan pengertian perkawinan diatas bahwa perkawina merupakan ikatan lahir dan batin bagi laki-laki dan wanita. Oleh sebab itu maka suatu perkawinan mempunyai asas-asas dalam perkawinan berdasarkan Undang-Undang Nomor 1 Tahun 1974 Tentang Perkawinan. Asas- asas initercantum dalam pada penjelasan umum 3(tiga) UndangUndang perkawinan, adapunasas- asas yang tercantum adalah :

a. Bahwa perkawinan adalah untuk membentuk keluarga bahagia dankekal. Untuk itu suami istri perlu saling membantu dan melengkapi, keduanya dapat mengembangkan kepribadian untuk mencapai kesejahteraan yang bersifat material dan spiritual.

b. Perkawinan sah bilamana dilakukan menurut hukum masing- masing agama dan kepercayaannya, dan di samping itu tiap-tiap perkawinan harus dicatat menurut perundangan yang berlaku.

c. Perkawinan harus memenuhi administrasi dengan jalan mencatatkan diri pada kantor pencatatan yang telah ditentukan oleh perundang- undangan.

d. Perkawinan menurut asas monogami, meskipun tidak bersifat mutlak karena masih ada kemungkinan untuk beristri lebih dari seorang, bila dikehendaki olehpihak- pihak yang bersangkutan dan ajaran agamanya mengijinkan untuk itu ketentuan harus memenuhi ketentuanketentuan yang diatur dalam undangundang.

e. Perkawinan dilakukan oleh pihak yang telah matang jiwa raganya atau telah dewasa, kematangan ini sesuai dengan tuntutan jaman di manabaru dilancarkan keluarga berencana dalam rangka pembangunan nasional.

f. Memperkecil dan mempersulit perceraian.

g. Kedudukan suami istri dalam kehidupan perkawinan adalah seimbang baik kehidupan rumah tangga maupun dalam kehidupan masyarakat.

Perkawinan adalah salah satu peristiwa yang sangat penting dalam kehidupan masyarakat adat, sebab perkawinan bukan hanya menyangkut kedua mempelai, tetapi juga orang tua kedua belah pihak, saudarasaudaranya, bahkan keluarga mereka masingmasing. Dalam hukum adat perkawinan itu 
bukan hanya merupakan peristiwa penteng bagi mereka yang masih hidup saja. Tetapi perkawinan juga merupakan peristiwayang sangat berarti serta yang sepenuhnya mendapat perhatina dan diikuti oleh arwaharwah para leluhur kedua belah pihak. ${ }^{21}$

Berkenan dengan adanya hubungan antara laki-laki dan perempuan untuk sebuah perkawinan bagi masyarakat adat maka menurut Hukum Adat pada umumnya di Indonesia perkawinan itu bukan sajaberarti sebagai perikatan Perdata tetapi juga merupakan "Perikatan Adat" dan sekaligus merupakan perikatan kekerabatan dan kekeluargaan. Jadi terjadinya suatu ikatan perkawinan bukan semata-mata membawa akibat terhadap hubungan-hubungan keperdataan, seperti hak dan kewajiban suami isteri, harta bersama kedudukan anak, hak dan kewajiban orang tua, tetapi juga menyangkut hubungan-hubungan adat istiadat, kewarisan kekeluargaan, dan kekerabatan dan ketetanggaan serta menyangkut upacaraupacara adat dan keagamaan. Begitu juga menyangkut kewajiban mentaati perintah dan larangan keagamaan, baik dalam hubungan manusia dengan Tuhannya maupun hubungan manusui dengan manusia dalam pergaulan hidup agar selamat didunia dan selamat di Akhirat. ${ }^{22}$ Demikian pula diketengahkan oleh

21 http://www.lutfichakim. com/2012/01/perkawinan-menurut-hukum-adat-dan. html diakses hari senin tanggal 5 Maret 2018

22 Hilman Hadikusuma,2007, Hukum Perkawinan Di Indonesia Menurut Perundangan $\mathrm{Hu}$ kum Adat Hukum Agama (Bandung: Mandar Maju,),
Teer Haar menyatakan bahwa : Perkawinan adalah urusan kerabat, urusan keluarga, urusan masyarakat, urusan martabak dan urusan pribadi $^{23}$

Van Gennep menamakan semua upacara perkawinan sebagai "Rites De Passage" (upacara peralihan) yang melambangkan peralihan status dari masing masing mempelai yang tadinya hidup sendiri sendiri berpisah setelah melampaui upacar yang disyaratkan menjadi hidup bersatu sebagai suami istri, merupakan somah sendiri, suatu keluarga baru yang berdiri serta mereka bina sendiri. ${ }^{24}$

Perkawinan dalam arti "Perikatan Adat" ialah perkawinan yang mempunyai akibat hukum terhadap hukum adat yang berlaku dalam masyarakat yang bersangkutan. Akibat hukum ini telah ada sejak sebelum perkawinan terjadi, yaitu misalnya dengan adanya hubungan pelamaran yang merupakan “ Rasa senak " (hubungan anak-anak, bujang gadis) dan "rasa Tuha" (hubungan orang tua keluarga dari pada calon suami istri). Setelah terjadinya ikatan perkawinan maka timbul hak-hak dan kewajiban orang tua termaksud anggota keluarga , kerabat menurut hukum adat setempat yaitu dengan pelaksanaan upacara adat dan selanjutnya dalam peran

hlm. 8 .

23 Hilman Hadikusuma, 2003,PokokPokok pengertian Hukum Adat, Alumni Bandung, hal:8

24 http://serlania.blogspot. co.id/2012/01/hukum-perkawinan-adat.html diakses Hari Jumat Tanggal 23 Maret 2018 Jam 13:30 Wib 
serta membina dan memelihara kerukunan, keutuhan dan kelenggengan dari kehidupan anak-anak mereka yang terlibat dalam perkawinan..$^{25}$

Menurut Hukum Adat di Indonesia perkawinan itu dapat berbentuk dan bersistim perkawinan jujur dimana pelamarandilakukan pihak pria kepada pihak wanita dan setelah perkawinan, isteri mengikuti tempat kedudukan dan kediaman suami hal ini biasa dijumpai di (Bantul, Lampung, Bali) kemudian "Perkawinan Semanda " dimana pelamar dilakukan oleh pihak wanita kepada pihak pria dan setelah perkawinan suami mengikuti tempat kedudukan dan kediaman istri hal ini bisa dijumpai didaerah (Minangkabau, Semendo Sumatera Selatan) dan perkawinan bebas yaitu di (Jawa, Mencur, Mentas) dimana pelamaran dilakukan oleh pihak pria dan setelah perkawinan kedua suami istri bebas menentukan tempat kedudukan dan kediaman mereka, menurut kehendak mereka, yang terakhir ini banyak berlaku dikalangan masyarakat keluarga yang telah maju (Modern). ${ }^{26}$

Dari pernyataan-pernyataan diatas dapat penelitisampaikan bawha nilai-nilai budaya dari masyarakat yang

\footnotetext{
25 http://serlania.blogspot. co.id/2012/01/hukum-perkawinan-adat.html diakses
}

Hari Jumat Tanggal 23 Maret 2018 Jam 13:30 Wib 26 http://bloghukumumum.blogspot. co.id/2010/04/pengertian-perkawinan-menurut-hukum.html diakses Hari Jumat Tanggal 23 Maret 2018 Jam 13:30 Wib bersangkutan, asal saja segala sesuatunya tidak berkepentingan dengan kepentingan umum, perkawinan yang bersifat antar agama, oleh karena perbedaan adat yang hanya menyangkut perbedaan masyarakat bukan perbedaan keyakinan.

Ikatan hidup bersama antara seorang pria dan wanita, yang bersifat komunal dengan tujuan mendapatkan generasi penerus agar supaya kehidupan persekutuan atau clannya tidak punah, yang didahului dengan rangkaian upacara adat. Van Gennep menamakan semua upacara perkawinan sebagai "Rites De Passage" (upacara peralihan) yang melambangkan peralihan status dari masing masing mempelai yang tadinya hidup sendiri sendiri berpisah setelah melampaui upacar yang disyaratkan menjadi hidup bersatu sebagai suami istri, merupakan somah sendiri, suatu keluarga baru yang berdiri serta mereka bina sendiri. Rites De Passage terdiri atas 3 tingkatan :

\section{Rites De Separation yaitu upacara} perpisahan dari status semula.

2. Rites De Marga yaitu upacara perjalanan kestatus yang baru.

3. Rites D'agreegation yaitu upacara penerimaan dalam status yang baru. ${ }^{27}$

Dari pendapat diatas bahawa ikatan perkawinan merupakan peralihan status

http://bloghukumumum.blogspot. co.id/2010/04/pengertian-perkawinan-menurut-hukum.html diakses Hari Jumat Tanggal 20 Januari 2019 Jam 13:30 Wib 
dari masing-masing mempelai dimana pada walnya hidup sendiri tanpa ikatan dengan orang lain menjadi hidup bersama sebagai suami istri. Sebelum menjalankan perkawinan yang tentunya perlu adanya penilaian yang dilakukan oleh satu sama lain, penilaian tersebut bertujuan untuk menerima kekurangan dan kelebihan dari pasangan. Oleh sebab itu beberapa faktor yang mengakibatkan seseorang dapat membatalkan perkawinan

\section{Ketakutan}

Ketakutan adalah suatu tanggapan emosi terhadap ancaman. Takut adalah suatu mekanisme pertahanan hidup dasar yang terjadi sebagai respons terhadap suatu stimulus tertentu, seperti rasa sakit atau ancaman bahaya. Beberapa ahli psikologi juga telah menyebutkan bahwa takut adalah salah satu dari emosi dasar, selain kebahagiaan, kesedihan, dan kemarahan. ${ }^{28}$

\section{Faktor Sosial}

Gagal menikah, bisa juga karena status sosial pasangan yang tidak satu level, perbedaan budaya atau permusuhan antar keluarga masing-masing pasangan. Perbedaan etnis dan agama juga jadifaktor penyebab batalnya pernikahan. "Sudah tahu beda suku atau agama, pertama kayaknya bisa nih (dijalankan), tapi baru tahu ternyata emang nggak siap.

\section{Kehadiran Orang Ketiga}

Berdasarkan faktor ketiga, dimana 28 https://id.wikipedia.org/wiki/Ketakutan diakses Hari Jumat Tanggal 20 Januari 2019 Jam 13:30 Wib calon pengantin menemukan bahwa pasangan tidak cukup untuknya, kehadiran orang ketiga sangat mungkin membuat rencana pernikahan akhirnya batal.

\section{Hati yang Kurang Mantap}

Dilihat dari sisi psikologis, selain ketidaksiapan juga ketidakmantapan. Ratih berujar, tidak mantap belum tentu karena tidak siap. Ada kesiapan secara mental, namun terdapat hal-hal yang membuat sang calon pengantin menjadi ragu. Misalnya saja,secara finansial maupun sosial dia merasa sudah siap. Namun ada sesuatu yang dirasa masih mengganjal. ${ }^{29}$

\section{METODE PENDEKATAN}

Metode pendekatan yang digunakan dalam penelitian ini adalah metode pendekatan yuridis sosiologis, Metode pendekatan yuridis sosiologis ini memandang hukum sebagai pranata sosial yang secara riil dikaitkan dengan sebab-sebab sosial yang lain. Karakteristik yang dimiliki pada penelitian hukum sosiologis; ${ }^{30}$

1. Penelitian hukum sosiologis menggunakan data sekunder sebagai data awalnya, yang kemudian dilanjutkan dengan data primer atau data lapangan.

2. Definisi operasionalnya dapat diambil

$29 \mathrm{http} / / /$ bloghukumumum.blogspot. co.id/2010/04/pengertian-perkawinan-menurut-hukum.html diakses Hari Jumat Tanggal 23 Maret 2018 Jam 13:30 Wib

30 Amirudin, SH, M.Hum dan Zainal Asikin, SH, SU ; Pengantar Methode Penelitian Hukum, 2004, Rajawali Press, hlm. 133 
dari peraturan undang-undang, khususnya terhadap penelitian yang hendak meneliti efektifitas suatu undang-undang.

3. Hipotesis kadang-kadang diperlukan, misalnya penelitian yang ingin mencari hubungan (korelasi) antara berbagai gejala atau variabel.

4. Akibat dari jenis datanya (data sekunder dan data primer), maka alat pengumpul datanya terdiri dari studidokumen : pengamatan (observasi), dan wawancara (interview). Pada penelitian hukum sosiologis selalu diawali dengan studi dokumen, sedangkan pengamatan (observasi) digunakan pada penelitian yang hendak mencatat atau mendeskripsikan perilaku (hukum) masyarakat. Wawancara (interview) digunakan pada penelitian yang mengetahui misalnya, presepsi, kepercayaan, motivasi, informasi yang sangat pribadi sifatnya.

5. Penetapan sampling harus dilakukan, terutama jika hendak menelitiperilaku (hukum) warga masyarakat, dalam penarikan sampel, hendaknya diperhatikan sifat atau ciri-ciri populasi.

6. Pengolahan data dapat dilakukan baik secara kualitatif dan / kumulatif. Pendekatan yuridis sosiologis ini penelitikombinasikan dengan deskriptif analisis, untuk menggambarkan dan menganalisa fakta-fakta yang terjadi atau terkumpul dan tampak sebagaimana adanya pada saat penelitian akan dilakukan.

a. Penelitian kepustakaan (library research), Yaitu dengan mempelajari buku-buku literatur yang ada hubungannya dengan masalah penelitian

b. Penelitian lapangan (field research)

Yaitu melakukan penelitian secara langsung ke lapangan untuk mendapatkan data dengan cara mengamati begaimana mekanisme Desa Mengkirai Kecamatan Kayan Hilir Kabupaten Sintang

\section{PEMBAHASAN}

Hukum adat atau hukum tidak tertulis merupakan landasan dalam menentukan perilaku yang baik dan buruk. Hukum adat memiliki sanksi tertentu apabila ada perilaku yang menyimpang atau tidak sesuai dengan tatanan norma dan kaidahkaidah kesusilaan. Hasil penelitian terhadap batalnya melaksanakan perkawinan diDesa Mengkirai Kecamatan Kayan HilirKabupaten Sintang disampaikan secara langsung oleh Ketua Adat Bapak Yulianus Bernabas mengenai pembatalan perkawinan yang dilakukan secara sepihak, baik laki-laki maupun perempuan. Pembatalan perkawinan yang dilakukan secara sepihak baik laki-laki maupun perempuan, dalam masyarakat dayak 
Desa merupakan salah satu adat ingkar, yang mana adat ingkar tersebut haruslah dipenuhi sebagai pertanggungjawaban bagi salah satu pihak karena telah dikatakan berbohong (ngemula). Adat Ingkar ini diberikan kepada pihak yang membatalkan perkawinan yang telah direncanakan oleh masing-masing keluarga calon mempelai, oleh karena itu terdapat beberapa sanksi adat tergantungdari kapan salah satu pihak membatalkan perkawinan. Berdasarkan Kebiasan adat membatalkan perkawinan pada masyarakat Dayak Desa, adat Ingkar terdiri dari atas :

1. Adat Ingkar setelah pertunangan dan sudah menentukan tanggal bulan dan tahun Perkawinan

2. Adat ingkar pada saat akan dilaksnakan Perkawinan hari yang ditentukan sudah dekat acara pelaksanaan ${ }^{31}$

Adapun bentuk sanksi adat ingkar setelah pertunangan adalah sebagai berikut:

Hantaran pertunangan yang diberikan laki-laki pihak kepada Perempuan

a) Satu Pasang Cincin untuk pertunangan

b) Kain sarung (Kain tapih)

c) Bedak

d) Lipstik

e) Sabun

f) Ember sabun

g) Odol

h) sikat gigi

i) Beras

j) Baju
k) Sandal
1) Pakaian tidur wanita

Dari semua hantaran yang diberikan kepada pihak perempuan haruslah dikembalikan kepada pihak laki-laki karena telah membatalkan perkawinan baik pihak laki-laki maupun perempuan, selain itu pembayaran adat yang berupa Tempayan, babi 1 rinti, ayam 1 ekor, beras 4 kl (6 kulak), besi (paku), Kain sarung (kain Tapih) uang pembuka kata masing-masing pihak Rp. 50.000, dan uang penutup malu Rp 1.000.00, kisaran adat tersebut haruslah di penuhi oleh pihak yang membatalkan perkawinan. ${ }^{32}$

Adapun proses terjadinya adat ingkar Perkawinan adalah sebagai berikut :

1. Laporan dari salah satu keluarga baik pihak laki-laki maupun perempuan kepada pengurus adat.

2. Pengurus adat akan mengundang keluarga yang melaporkan maupun yang dilaporkan kepada pengurus adat

3. Pengurus adat akan menentukan tanggal dan bulan untuk mempertemukan kedua belah pihak.

4. Menyampaikan sanksi adat ingkar kepada keluarga yang membatalkan perkawinan.

5. Pemenuhan adat Ingkar harus dilaksankan

Yulianus Bernabas Ketua adat Desa, di Desa Mengkirai Kecamatan Kayan Hilir Kabupaten Sintang Tanggal 10 April 2019

32 Hasil wawancara dengan Bapak Yulianus Bernabas Ketua adat Desa, di Desa Mengkirai Kecamatan Kayan Hilir Kabupaten Sintang Tanggal 10 April 2019 
sesuai dengan kebiasaan yang berlaku pada masyarakat Desa.

6. Dihadiri oleh keluarga kedua belah pihak serta pengurus adat Desa

7. Disaksikan oleh Perangkat Desa ${ }^{33}$

Sedangkan Adat ingkar pada saat akan dilaksnakan Perkawinan hari yang ditentukan sudah dekat atau acara pelaksanaan pesta perkawinan sudah disiapkan, maka bagi pelanggar adat ingkar perkawinan baik lakilaki maupun perempuan haruslah mengganti dari segala biaya-biaya yang telah dikeluarkan oleh salah satu pihak, serta memenuhi sanksi adat yang sudah ditetapkan oleh ketua adat 2 (dua) kali lipat, dan mengembalikan barang hantaran 2 (dua) kali lipat. ${ }^{34}$

Berdasarkan Hasil wawancara penelitidengan salah satu warga di Desa Mengkirai Kecamatan Kayan Hilir Kabupaten Sintang yang telah membatalkan perkawinan menyatakan bahwa saknsi adat ingkardi sampaikan oleh keluarga perempuan sebagai tuntutan karena telah membatalkan perkawinan yang telah direncanakan, tuntutan tersebut disampaikan melalui pengurus adat Desa dan disaksikan oleh keluarga (laki- laki). Dalam mengisi tuntutan adat ingkar membatalkan setelah pertunangan dilakukan dirumah ketua adat karena sesuai dengan permintaan dari keluarga pihak perempuan dan adat ingkar haruslah dibayar pada saat

$\begin{array}{ll}33 & \text { ibid } \\ 34 & \text { ibid }\end{array}$

pelaksanaan adat tersebut.

Adapun tuntutan dari pihak keluarga perempuan dalam sanksi adat Ingkar yaitu memenuhi kisaran adat yang disampaikan oleh pengurus adat yang berupa Tempayan, babi 1 rinti, ayam 1 ekor, beras 4 kl (6 kulak), besi (paku), Kain sarung (kain Tapih) uang pembuka kata masing-masing pihak Rp. 50.000, dan uang penutup malu Rp 1.000.00, dan pihak perempuan mengembalikan hantaran yang telah diberikan pada saat acara pertunangan. Hantaran tersebut salah satu simbol meminta pihak perempuan untuk dijadikan istri, karena setelah pertunangan saya membatalkan hubungan selanjutnya, maka dikembalikanlah hantaran yang saya berikan, yang artinya bahwa melepaskan ikatan yang pernah terjadi antara saya dengan MG (inisial). ${ }^{35}$

Berdasarkan hasil wawancara penelitidengan Sekertaris Desa Mengkirai Bapak Yohanes Pobas mengatakan bahwa apabila permasalahan adat yang terjadi diwilayah Desa Mengkirai, maka Ketua Adat akan memberikan informasi serta mengundang perangkat desa untuk hadir dalam setiap penyelesaian adat, karena lembaga adat merupakan salah satu bagiandari pemerintahan di Desa. ${ }^{36}$

Penyelesaian adat biasanya dilakukan dihadapan pengurus adat serta perangkat desa, 35 Hasil Wawancara dengan salah satu masyarakat yang telah membatalkan perkawinan setelah pertunangan Mengkirai 25 April 2019

36 Hasil wawancara dengan sekertaris Desa Mengkirai Kecamatan Kayan Hilir Kabupaten 
karena adat yang berlaku pada masyarakat Desa secara tidak langsung melibatkan perangkat desa untuk dimintai pendapat serta saran dalam menyelesaikan adat, kecuali apabila yang berkenaan takaran serta sanksi adat, hal tersebut sudah tertuang didalam buku adat yang berlaku pada masyarakat, khususnya masyarakat di Desa Mengkirai Kecamatan Kayan Hilir Kabupaten Sintang. ${ }^{37}$ Dalam pemberian sanksi adat ingkar perkawinan bukan sekedar pemberian dan pemenuhan adat yang dilakukan oleh salah satu pihak baik laki-laki maupun perempuan, akan tetapi sebagai wujud dari pemberianrasa malu yang telah dilakukan, karenatelah dianggap mengingkari dan menoda dari kesepakatan yang telah dilakukan baik keluarga laki-laki maupun keluarga perempuan. Oleh sebab itu perlu adanya sanksi adat diberikan kepada salah satu pihak yang membatalkan perkawinan supaya apa yang telah direncanakan secara bersamasama dilaksanakan sesuai dengan apa yang diinginkan. ${ }^{38}$

\section{KESIMPULAN}

Dari beberapa penjelasan pada hasil pembahasan diatas maka dapat penelitisimpulkan sebagai berikut :

1. Bahwa Pembatalan perkawinan yang

Sintang Tanggal 11 April 2019

37 ibid

38 Hasil wawancara dengan Bapak

Yulianus Bernabas Ketua adat Desa, di Desa Mengkirai Kecamatan Kayan Hilir Kabupaten Sintang Tanggal 10 April 2019 dilakukan secara sepihak baik laki-laki maupun perempuan, dalam masyarakat dayakDesamerupakansalahsatuadatingkar, yang mana adat ingkar tersebut haruslah dipenuhi sebagai pertanggungjawaban bagi salah satu pihak karena telah dikatakan berbohong (ngemula). Kisaran adat ingkar membatalkan perkawinan adalah sebagai berikut : Tempayan, babi 1 rinti, ayam 1 ekor, beras 4 kl (6 kulak), besi (paku), Kain sarung (kain Tapih) uang pembuka kata masing-masing pihak Rp. 50.000, dan uang penutup malu Rp 1.000.00, dan apabilaadat ingkar sudah mempersiapkan acara perkawinan maka dikenakan dua kali lipat dari kisaran adat yang telah ditentukan.

2. Bahwa beberapa faktor sehingga masyarakat di Desa Mengkirai Kecamatan Kayan Hilir Kabupaten Sintang dalam membatalkan perkawinan diantaranya adalah kesiapan yang belum sempurna, serta kehadiran orang ketiga sehingga mempengaruhi pembatalan perkawinan.

\section{DAFTAR PUSTAKA}

\section{$\underline{\text { Referensi Buku }}$}

Bushar Muhhamad, 1981, Asas-Asas Hukum Adat Suatu Pengantar, Pradya Paramita, Jakarta

2000, Pokok-

Pokok Hukum Adat, Pradya Paramita, Jakarta

Bambang Sugono, Metode penelitan Hukum, raja Grafindo, Persada, Jakarta

Hadari Nawawi, 2007, Metode Penelitian Bidang 
84 Perahu, Volume 9 Nomor 1, Maret 2021, Hlm 68-84

Sosial, Gajah Mada University Press, Yokyakarta,

H.R. van Heekeren.1955 Penghidupan dalam zaman Pra Sejarah diIndonesia. Edisi terjemahan. Jakarta: Lembaga Kebudayaan Indonesia.

I Gede A.B. Wiranata, 2005, Hukum Adat Indonesia, Perkembangannya dari Masa Kemasa, Citra Aditiya Bakti, Bandung

Hilman Hadikusuma, Hukum Pidana Adat, rajawali Jakarta,

Kusumadi, Pedoman Pelajaran Tata Hukum, Aksara Baru Jakarta.

Mustaru Pide Suriyaman,2014, Hukum Adat Dahulu, Kini, dan Akan Datang Prenadamedia Group Jakarta

Ronny Hanitijo Soemitro,1983, Metode Penelitian Hukum, Jakarta, Ghalia Indonesia,

Soerojo Wigjodiporo, Pengantar dan AsasAsas Hukum Adat, Haji Masagung, Jakarta,

Soerjono Soekanto,Pokok-pokok Sosiologi Hukum, Raja Grafindo Persada Jakarta .................Meninjau Hukum Adat Indonesia Suatu Pengatar Untuk Mempelajari Hukum Adat, Rajawali Jakarta, Soemitro Ronny H, 1983, Metode Penelitian Hukum, Jakarta, Ghalia 1983 
Gadion,, Sanksi Adat Batalnya Melaksanakan Perkawinan 85 
86 Perahu, Volume 9 Nomor 1, Maret 2021, Hlm 68-84 